\title{
Gurney and Fritz
}

Writing in 1917 to the music critic Marion Scott, Ivor Gurney entertains his friend with the 'casual catchwords' of the trenches. A rifle is a 'bundoob', a revolver a 'peashooter', a good officer a 'toff' or 'gentleman'. Any soldier, looked for but not present, is assuredly to be found 'On the wire, at Loos' or - 'a lighter answer' in Gurney's estimation - 'Gassed at Mons'. The enemy rejoices in a number of appellations according to circumstance. 'Germans are known, affectionately, as Fritzes, Allemans, or “Johnny”, Gurney reports. 'The Germans, in anger, are referred to as “them _ _ bastards”.' (Gurney’s underscoring denotes a blankedout expletive evidently more severe than 'bastards'.) Even so, the soldier under bombardment chooses an affectionate term to keep sight of the silver lining: 'More iron rations for Fritz'.

Fritz is conspicuously absent from most of Gurney’s war poetry. Severn \& Somme (1917) fails to mention him at all, and in War's Embers (1919) only 'The Target', a wobbly rewriting of Thomas Hardy’s ‘The Man He Killed’, acknowledges an antagonist: 'I shot him, and it had to be / One of us!'. ${ }^{2}$ So unsuccessful is the poem that its final line, 'This is a bloody mess indeed', risks sounding self-referential. Perhaps chastened by the experience, Gurney does not attempt another poem about Fritz until the mid-1920s. There are, in the meantime, deadlier enemies to contend with. 'The Ford' curses the ubiquitous Somme mud, 'evil past any disaster / Of facing Germans'; ${ }^{3}$ and like the most celebrated of his soldier-poet contemporaries, Gurney prefers to turn his fire on the enemy behind the lines. Owen and Sassoon had denounced the politicians, the women, the sanctimonious Bishops, the newspaper barons, the scarlet majors. Although Gurney does not dwell on those betrayers at such length, his pitch of indignation reverberates through the sonnet 'To the Prussians of England, ${ }^{4}$ a revenge fantasy (written during that month of revolutionary fervour, October 1917) in which the poet dreams of taking a knife to the cancerous body politic. A few days later, to Marion Scott, Gurney attempts to find consolation in catastrophe: 'Thank God, this war was not a six months affair, for our victory would have throned Prussia at Westminster' 
(CL, p. 353). His assumption that the war's longevity has frustrated the war-mongers' political agenda will cause him renewed despair after its conclusion.

Resisting such adversaries leaves little time to devote to Fritz, whose rare appearances in the poetry of the war befit his rare appearances in the war itself: as Gurney explains, 'It is a weird queer war - this, against unseen enemies’ (CL, p. 101). Gurney’s brief account in 'Near Vermand' of 'Germans seen actually' (CP, p. 158) conveys the ontological surprise as well as the newsworthiness of the event. To an unprecedented degree, the First World War is experienced haptically, and Gurney is peerless in his descriptions of those intimately tactile assaults and respites: 'pangs and ill body-creepers / Stilled with the cold the cold bringing me sane' ('Half Dead', $R W$, p. 25). For deeply entrenched soldiers under such conditions, sight is tempted upwards to the changing expanse of the skies. Again, Gurney stands as exemplar rather than exception, writing a poetry of sky-gazing which is filled with stellar and crepuscular topoi, with sun and clouds and the connoisseur's palette of ‘slate and pink and blue above the frightened / Mud fields' ('Laventie Dawn’, RW, p. 28). That transferred epithet - 'frightened' - points to the contrast between the skies' refuge and the fearful mudscape into which rival armies must secrete themselves, troglodytic, in order to survive.

Their shared suffering allows growing sympathy between Tommy and Fritz, who are so many Isaacs to their fathers' Abraham, or Christ-figures sacrificed by an unfeeling deity. 'In the mind of all the English soldiers I have met', Gurney writes, ‘there is absolutely no hate for the Germans, but a kind of brotherly though slightly contemptuous kindness - as to men who are going through a bad time as well as themselves' (CL, p. 215). 'Contemptuous kindness': oxymoron is the figure best equipped to reconcile, or to hold in creative tension, the competing demands of art and violence, as formal representation confers on war a terrible beauty; and the recourse to oxymoron is still more certain in the portrayal of an enemy who is a mirror-image, a fellow sufferer. The underground voice of Wilfred Owen’s ‘Strange 
Meeting' identifies itself as belonging to 'the enemy you killed, my friend' 5 - enemy by political decree, friend (decisively) by natural instinct. But whereas Owen draws a clean distinction between the personal ('my friend') and the national ('the enemy'), Gurney's 'contemptuous kindness’ qualifies the allowed consanguinity. That 'kind... of kindness' remains tainted, if only 'slightly'. Fritz may be a brother in arms, but brothers are not, at least not necessarily, friends.

Gurney’s wartime correspondence mentions Fritz with far greater regularity than his wartime verse. Only after the war, in poetry unpublished for decades after his death in 1937 (and much of which remains unpublished today), does he develop a style sufficiently alive to the emotional complexities and disruptive shifts of register provoked by the subject. Geoffrey Hill has anatomised Gurney’s genius for grasping ‘the way words and tones sit within our lives and the way they situate the life of one man in relation, or disrelation, to his comrades and his superiors’ ${ }^{6}$ Hill focuses on a passage from a letter to Scott in November 1917: 'There’s a bit of luck; owing to slight indigestion (presumably due to gas; wink, wink!) I am to go to Command Depot for two months' (CL, p. 363). That 'wink, wink!', according to Hill, 'mimes a skiver’s self-congratulation', conveying the 'uneasy jauntiness of the cornered man'. Increasingly, Gurney's post-war poetry becomes capable of exploring and miming the same tonal relations and disrelations which characterise his letters; but his mimicries are provoked more by his engagements with Fritz than by the simpler dealings with comrades or superiors. The sudden cluster of poems in 1925 referring to Fritz comprises the most tonally nuanced representation of the brotherly enemy by any British soldier-poet.

‘Chaulnes’ (1925), for example, is Gurney’s belated account in verse of an event first described in several letters of 1917. Having got lost amidst a maze of trenches, a brave and popular comrade had blundered into enemy lines, never to be seen again. Finally, his disappearance had been solved with the discovery of his grave following a British advance: 'Quite a fine little wooden cross had been erected there; the Germans had done well; it was 
better than we ourselves would have given him’ (CL, p. 239). ${ }^{7}$ In the poem, Gurney witnesses the burial imaginatively:

Later, we found our comrade's grave, they had buried him ......

(Found his body, loved his face, carefully had carried him, tended him.)

And heard the words of commemoration said ceremonious over

The white cross and the little mound; Europe even now had care

Of Europe; this great spirit killed in the reckless night;

Buried with danger's tenderness by his loving enemies.

The Gloucesters watching the cross, craftsman's work, past their loss

Remembered gratitude, and praised chivalry for this

True burial of a comrade loved best of all the companies.

Honoured the care had fashioned so honourable a cross. ${ }^{8}$

The burial mound becomes the site of mutual recognition. The Germans honour the dead enemy soldier, and in their turn they are honoured by the Gloucesters, whose poet will eventually honour both sides in the act of writing 'Chaulnes'. 'Europe even now had care / Of Europe': this most internecine of civil wars is healed by Gurney's vocabulary of respect, which in the space of ten lines draws enemies into close relation by incorporating love, commemoration, care, tenderness, honour, praise, gratitude and chivalry. The phrases ‘danger's tenderness' and 'loving enemies’ resort once more to oxymoron as the figure best able to make sense of war's extremes. And the mirroring of the rival armies is enacted via echoes and repetitions - 'loving enemies', 'loved of all the companies' - with the rhyme 'enemies' / 'companies' bringing antagonists together in (not quite perfect) harmony. Later in the poem, Gurney remembers finding 'many postcards / Of German towns nailed up for memory's rewards', and 'Two great books of plainsong in noble print'. The detritus of the enemy retreat reflects back to Gurney his own image as a homesick soldier and as a composer inspired by the German musical heritage. ${ }^{9}$ 
'Chaulnes' studiously avoids reference to the awkward truth that, before the Germans paid their ceremonious respects to the brave Englishman, they killed him. He was 'killed in the reckless night', but the poem never spells out by whom; and Gurney's weakness for transferred epithets helps to conceal agency. Pillboxes, not Germans, are 'damned', and destruction is caused by 'devil-of evil war' [sic]. The poem's sulphurous judgements attach to objects, to abstract forces, and to a shared situation, not to one side rather than the other. Gurney's war letters even express pity for Fritz on account of 'the terrible power of our explosives’ (CL, p. 136): 'Theirs of course do damage enough, but nothing comparable’ (CL, p. 103). The necessary decorum of a war between brothers can make technological superiority seem a trifle unsporting, although Gurney’s generosity has its limits. In August 1917, frustrated by the duration of the war, he lashes out murderously at Fritz: 'First to squash him to juice then blow him sky high to fall to Hell, for a sycophantic self deceiving treacherous Thug' (CL, p. 303). Fritz is sycophantic and self-deceiving because by refusing to betray his bellicose fathers, he betrays Europe and his brothers. However, post-war poems like 'Chaulnes' find that criticism harder to sustain, and rarely indulge as much as a fleeting rage against the Germans. Time has exacerbated Gurney’s own sense of having been betrayed, both by the institutions which (he alleges) have tortured him and confined him to an asylum distant from his beloved Gloucestershire, and by those English Prussians who, far from rewarding the survivors of the war, have left them to fester on 'State-doles' ('Strange Hells', $R W$, p. 81). None of this retrospectively justifies Fritz's cause in Gurney's eyes, but it does demonstrate that he had no monopoly on self-deception.

1925, the year of the Fritz poems, was prolific for Gurney. In January he composed numerous songs, and wrote a collection of poetry. During February he wrote The Book of Five Makings (eventually published in 1995), the collection which includes 'Chaulnes'. Even by those standards, March turned out to be astonishingly productive, with seven song settings and four collections of poetry. April saw two collections and four song settings, and although 
Gurney’s output seems to have declined from such frenzied peaks in subsequent months, he continued to produce collections of poetry and song settings throughout the year and into 1926. Not all the poems are masterpieces, but the quality is less erratic than might be supposed, which makes the tendency of successive editors to overlook so much work from this period all the more perplexing. 'Memories of Honour', a 23-poem collection from March 1925, is representative in its neglect: to date, only seven poems have appeared in print. One of its longer poems, ‘The Man’, obligingly revisits the very subject which prompts Gurney’s guilty self-congratulation in the letter to Scott which so fascinates Geoffrey Hill - the achieving of a Blighty after exposure to gas:

yet gas changed all;

Instead of moving South with the Fifth army, Chokes and gasps of gas moved a doctor's sympathy (Three weeks in needing rest - hoping a week to befall) And got to Blighty - as unexpectedly as ever any Of honest gas (but not much) got by a tale Of five hours gas bombardment, which was true (I brought that down) or keeping silence as to the Real reason - which was three weeks at Ypres, Without a rest (or laurel) (nor yet a cypress), Having seen Passchendaele lit with a flare of firs And Ypres a dawn light ruddy and golden of desire, The stuck tanks - and shook at our guns going in As my body would not stay still at such Hell of din... ${ }^{10}$

A glance at the number of dashes and parentheses is sufficient to appreciate Gurney's torturing syntax as he veers between self-blame and self-exculpation. Instead of moving south, Gurney moves a doctor’s sympathy; Blighty is 'got by a tale’, albeit a ‘true' one; and 
the gas suffered is 'honest' - '(but not much)' - as the transferred epithet raises questions about the levels of gas and the levels of honesty in the tale's telling. But just when it seems that Gurney has succeeded in pulling a fast one (wink, wink!), he launches into the 'Real reason', which is a neurasthenia induced by 'three weeks at Ypres' when trees burned and were obliterated and the poet's body shook with the shaking of the guns. The soldier must mime and deceive, and exaggerate a minor disorder, to gain the treatment he requires for serious illness.

'Memories of Honour' has an unusually high number of references to Fritz - more than Gurney's six published volumes can muster between them. ${ }^{11}$ And 'Fritz' is now the appellation of choice, comfortably outnumbering 'the Germans'. That decision enacts a familiarity between the two sides which can even become playful: Tommy and Fritz are portrayed as in cahoots, looking for a quiet life, condemned and cornered, uneasily jaunty. 'Fritz, I am not high minded, / I have no proud looks', Gurney begins 'Reves Ambitieux' [sic], jokingly apotheosizing Fritz by rewriting Psalm 131. 'Serenade’ recalls a period 'after the Somme' with neither side 'daring attacker / Or aggressor to be', and the sound of Schubert drifting over from the Germans’ wind-up gramophone is enough to prompt the Gloucesters to shout interlinguistic requests across no-man’s-land: “'Strauss is our favourite wir haben / Sich geliebt”' (CP, p. 240). In 'The Stokes Gunners', Gurney describes an occasion when 'Fritz and we were nearly on friendly terms' until a group of gunners ('O moral insects, $\mathrm{O}$ worms') sauntered into the sector to fire their missiles, immediately abandoning the Gloucesters to the whirlwind of retaliation. ${ }^{12}$

Another Fritz poem, 'La Rime’, ${ }^{13}$ shows Gurney’s unpublished genius to greatest effect:

Fritz caught a sight of a fatigue party going down -

Probably just ended - having escaped observation, 
So this offended Fritz and he let fly

With everything of powder, cordite or T.N.T.

One did his bootlace up, one lit his pipe and cursed

Ration tobacco, and said "Boys this is war at the worst,"

One blew his nose, one plucked at a dead nettle

Growing above the trench side - and one made rattle

The breech of his rifle in ragtime, nobody ran.

One having written seven lines to rhyme and scan,

(So to say) raised his umbrella and cursed Fritz -

Who never had, nor never would produce poets,

And at the Red House, said sudden, "I see that's the one,"

Finished his eighth line and blasted home-critics to bits.

'La Rime’ delineates more than just phlegmatism under fire, although its comedy predicts the extremes to which that national characteristic or caricature will later be taken in film and television. The more profound comedy of 'La Rime' derives from the mimicking of words and tones which any reader would reasonably expect to encounter in a Great War poem about a savage bombardment. Death is mentioned and, in a suitably explosive finale, people get 'blasted... to bits'. However, only a nettle turns out to be 'dead' (and, even then, only by name), and the detonation is purely figurative. Soldiers curse, as well they might, but the comic timing of Gurney’s enjambment - 'cursed / Ration tobacco' - ensures that “"war at the worst"” has less to do with Fritz's aggression than with the poor quality of what Gurney calls elsewhere 'The herb unfabled, the plant of peace, the king / Of comfort bringers' ('Tobacco', $R W$, p. 29). Shelling can be endured, substandard tobacco not. And the onomatopoeia, beloved of generations of schoolchildren, in Owen’s 'Anthem for Doomed Youth' - 'the stuttering rifles' rapid rattle' (OCP, p. 140) - meets more than its match in a soldier's musical accompaniment: 'one made rattle / The breech of his rifle in ragtime, nobody ran.' What 
Owen hears as 'monstrous anger', his staccato trochees underscored by alliteration, Gurney plays for laughs with ragtime anapaests.

Gurney situates himself in relation and disrelation to Fritz by means of these tonal performances. Fritz is 'offended' and 'let[s] fly', as violence is reduced to a bout of pique, compared with which the poet's anger at his critics sounds lethal. (The cliché 'blasted... to bits’ may threaten to regain its literal meaning, but - paradoxically - Gurney revitalises inert language by refusing the context's clear invitation to do so.) The cursing of Fritz becomes a mockery of genuine rage: the earlier curse against ration tobacco, and the accompanying action of raising an imaginary umbrella, dispel any suspicion of animosity. Adapting the petulant tones of the playground, the worst that can be said of Fritz is that he 'never had, nor never would produce poets'; and although Fritz must suffer the indignity of being made to rhyme with 'blasted... to bits', he is not the target even of fantasy violence. While his life is threatened by Fritz, the poet will not be distracted from imagining the wreck of his true enemies - those 'home-critics' against whom the finished verse will work the desired devastation.

In his wartime letters, Gurney admits to the usefulness of humour as a coping mechanism: '[trench mortars] often make me horribly afraid, but never past the possibility of making jokes; which must be my standard of paralytic fear’ (CL, p. 138). His response is hardly unique. The attitude under bombardment summed up by that cry 'More iron rations for Fritz!' seems to have been commonplace among the Gloucesters, if Gurney’s account can be trusted: 'Our men will gag before the Judgement seat and before the throne of Heaven, and not in the most refined language either, and smoking a fag the while’ (CL, p. 111). But humour proves unable to keep off fears indefinitely. After relaying to Scott the wisecracks of one joker, the next day Gurney must add a sombre postscript: 'My beloved gagster has come a cropper and gone into hospital with a breakdown' (CL, p. 111). These remarks prompt the reader to understand Gurney's humour as a reaction to extreme stress; and as such, they are 
manna to those who, trained in the poetry of Gurney's contemporaries, have firm expectations of how war poetry in general, and passive suffering in particular, should comport themselves. Perhaps 'La Rime' is not a funny poem after all, but a sombre poem by other means. And yet to argue that case is to make the poem smaller because less unsettling. In 'La Rime', Gurney toys with the taboo that the violence of war, whatever else it is allowed to be, can be funny.

Paying tribute to his own 'ingrained sense of humour’, Gurney reports in June 1916 that 'A whizzbang missed me by inches over my head and exploded ten yards from me - and the impression it gave and gives me now is chiefly of the comic' (CL, p. 101). It is the survivor's prerogative to feel amused, although his poetry takes much longer to see the funny side. His humour derives first from a sense of fatalism - 'I am more or less fatalistic' - and then from a sharp awareness of unreality and incongruity: 'I really have no part in [the war]', or as Gurney puts it with more passionate amazement later, 'Still a war on! and I still in it!' (CL, p. 167). Attempts by a brotherly enemy to kill him, and his own barely explicable duty to kill a brotherly enemy, constitute the most absurd comedy. This attitude, needless to say, resists the accepted narratives of the war. In turn, it has been resisted by many of Gurney's editors. So when P. J. Kavanagh publishes for the first time Gurney’s long poem 'The Retreat' (written in April 1925, one month after 'Memories of Honour'), he consigns it to the appendix of Collected Poems (CP, p. 344-348), explaining his decision in an editorial headnote which forewarns unsuspecting readers of the dangers ahead:

This long autobiographical poem, one of many, is included because Gurney begins to describe his front-line experiences - even the shooting at people - in comic terms. This is typical of a certain vein in Gurney (perhaps typical of certain aspects of war) and he would not be fully represented were it to be left out. ${ }^{14}$

Although it has fared marginally better than 'La Rime’, having at least been suffered into print, 'The Retreat' has gone unnoticed as a result of its prejudicial setting. Cordoned off in 
its appendix, the poem has endured the most oxymoronic of fates; it is simultaneously included in, and left out of, Collected Poems. For no other poem does Kavanagh provide a headnote. Such special treatment seems to have been motivated by anxiety: Gurney may not be 'fully represented' without the poem, but Kavanagh does not want to sanction 'The Retreat' by allowing it a proper presence. The reason given for the poem's inclusion turns out to be the reason why it cannot be included.

'The Retreat' is unusual for broaching the subject of 'shooting at people', never mind treating it 'in comic terms'. Eloquent about suffering and being killed, Great War poets keep their counsel when it comes to the business of killing. Exceptions are few and brief, such as the friendly enemy’s report of his death in 'Strange Meeting': ““for so you frowned / Yesterday through me as you jabbed and killed”' (OCP, p. 148). Sassoon's 'The Kiss' directly addresses 'Sister Steel' - that is, the soldier's bayonet - in a sexually violent fantasy whereby he may 'feel / The body where he sets his heel / Quail from your downward darting kiss. ${ }^{15}$ Gurney also pays homage to the bayonet, but as a relic from the heroic days of handto-hand, intimate combat. In 'Joyeuse et Durandal' (unpublished, from 'Memories of Honour'), he complains that the 'lovely' Joyeuse bayonet, which he once 'caressed... with long fingers', has been replaced by the Durandal: 'you are longer, certainly not stronger, / And have no looks to speak of' ${ }^{16}$ Looks are everything. If the bayonet is not quite obsolete in the Great War, Gurney knows that (notwithstanding the impression given by Owen and Sassoon) its killing power has been surpassed by technology. All the same, he expresses his relief when assigned to a machine-gun post, having never come to terms with 'the thought of sticking Germans' (CL, p. 285). This is not squeamishness about killing, because shooting Germans incites no similar concern. On the contrary, killing is a business to be undertaken with serio-comic diligence; and it descends, inevitably, into farce.

'The Retreat' describes Gurney’s part in a British advance following the Germans' tactical withdrawal to the Hindenberg line, in late March and early April 1917. After digging 
in to his new forward position, Gurney spots ‘three great Germans’ oblivious to his proximity. Taking care to 'waste no shot', he aims at the middle one, and fires: 'No move'. Then at the left one: 'No move'. And a third time, again without success. At that moment his platoon runs up, and the Germans - evidently better fed than the British and even 'over-fed' - vanish (despite their ample frames) ‘like record breakers’. Gurney’s exasperation is voiced as comedy:

How did I miss them! How did I miss?

But I refuse to believe (flatly refuse)

And believe that men may be shot through middle bodies

Before enemies without dropping - I who had hit posts

As hard as ghosts to hit in Verey lights of Laventie...

Posts and any echoing thing... It was, and yet is

Absurd to me to think the belly may not be wholly

Shot through - by a tiny Bullet of our Army

And the man not stand up without sign of folly

Or wound...

One of the disadvantages for the Germans of looking like 'comfortable Burghers' or 'country squires', at least compared with 'our poor scarecrows', is that they take up more space and are therefore more likely to be hit. Compensation comes from the fact that the bullet is less likely to damage anything vital as it passes through the body. That, at least, is the preferred explanation of a self-proclaimed crackshot who would otherwise be obliged to concede that he had missed from close range three times in a row. At no point are ethical considerations allowed to complicate the episode: the Germans are there to be shot, just as 'Posts and any echoing thing' had been shot under the Verey lights. Gurney harbours no hard feelings towards them, merely envy for their having been enjoying 'meals like millionaires'. Two of them are 'as nice men as I'd ever meet again', and although that niceness attaches to their 
physical appearance, the word inevitably brings connotations of decency. As the Germans disappear over the 'chalk slope borders', Gurney calls after them: ““Goodbye”’.

Later in the poem, Fritz proves himself to be a more proficient marksman. Sent forward in a party to cut wires, the poet is forced lower and lower into the 'too chalky' Vermand earth by machine-gun fire. As he goes forward again, a bullet at last finds its target:

suddenly my arm went blazing with bright ardour of pain:

The end of music... I knelt down and cursed the double

Treachery of Fritz to Europe and to English music:

Cursed Pomerania, Saxony, Wurtemburg, Bavaria,

Prussia, Rheinland, Mecklenburg, Pomerania

Again... (But had forgotten Franconia, Swabia)

Then said 'You chaps, she’s beginning to move again';

Borrowed a rifle - shot one shot to say 'These things were so'.

'My arm - she'll stay on yet: I believe it’s a Blighty.'

Gurney mercilessly exploits the comic potential of idioms which refuse to acknowledge the ridiculousness of the war. His zeugma mock-hysterically curses - as if they are of equal significance - Fritz's twin acts of treachery 'to Europe and to English music', although that second crime only damages vague plans for a post-war career as a pianist. 'La Rime' provides notice that curses in Gurney's war poetry are factitious, even satirical or humorous; here, the partial inventory of Bundesländer doubly damns Pomerania but allows Franconia and Swabia to escape unscathed. One kind of mimicry leads naturally to another, as Gurney mischievously affects the stiff upper lip of the public schoolboy: “"You chaps, she’s beginning to move again”; “My arm - she'll stay on yet: I believe it’s a Blighty”.' Gurney’s tone is predictive and parodic of English war films passim. As the injured man walks away from the Front towards 'Blighty and new hope', a moment of superiority allows him to 
conjoin Tommy and Fritz in their hooligan activities: 'And I left them all, vulgar soldiers to brawl'. At a distance, the two armies are rendered indistinguishable by their war, from which Gurney’s wound offers him welcome respite. But he will have to wait another six months before the effects of gas bring his war to an end. 'Of course', he will confide winkingly to Marion Scott, 'it might be gas' (CL, p. 337).

University of Exeter 


\section{Notes}

I am grateful to the Leverhulme Trust for a Philip Leverhulme Prize which allowed me to carry out this research; to Philip Lancaster for transcribing Gurney’s ‘Memories of Honour’; and to the Trustees of the Ivor Gurney Estate for permission to reproduce 'La Rime'.

${ }^{1}$ Ivor Gurney, Collected Letters [CL], ed. R. K. R. Thornton (Ashington and Manchester, 1991), p. 341, where Gurney's comment on the Germans is mistranscribed as 'them bastards'. The letter is ms ref 41.142 in the Gloucestershire Archives.

${ }^{2}$ Ivor Gurney, Severn \& Somme and War's Embers, ed. R. K. R. Thornton (Ashington and Manchester, 1987), p. 79.

${ }^{3}$ Ivor Gurney, Rewards of Wonder: Poems of Cotswold, France, London [RW] ed. George Walter (Ashington and Manchester, 2000), p. 45.

${ }^{4}$ Ivor Gurney, Collected Poems [CP], ed. P. J. Kavanagh, (Manchester, 2004), p. 34. This revised edition, published by Carcanet Press, replaces the Oxford University Press edition of 1982.

${ }^{5}$ Wilfred Owen, The Complete Poems and Fragments, i: The Poems [OCP], ed. Jon Stallworthy (1983), p. 148.

${ }^{6}$ Geoffrey Hill, ‘Gurney’s Hobby’, Collected Critical Writings, ed. Kenneth Haynes (Oxford, 2008), p. 425.

${ }^{7}$ F. W. Harvey, Gurney's friend and fellow poet, met with a happier fate. Having accidentally wandered into enemy trenches, he was captured and taken prisoner. Gurney expressed characteristic delight at the news of his survival: 'Tray bong!... I am freed from supposing him to be na pooh' (CL, p. 161).

${ }^{8}$ Ivor Gurney, Best Poems and The Book of Five Makings, ed. R. K. R. Thornton and George Walter (Ashington and Manchester, 1995), p. 137. 
${ }^{9}$ Collected Poems prints a small sample of Gurney’s poems in praise of German composers, including ‘Sonnet to J. S. Bach’s Memory’ (p. 54), ‘Thoughts on Beethoven’ (p. 133), and 'Bach - Under Torment’ (p. 174).

10 'The Man’ is G.21A.79-80 in Gurney’s papers held at the Gloucestershire Archives. The poem is inaccurately transcribed, minus its title, in Michael Hurd's biography The Ordeal of Ivor Gurney (Oxford, 1978), pp. 103-05.

${ }^{11}$ Gurney's published collections are: Severn \& Somme (1917); War's Embers (1919); Best Poems and The Book of Five Makings, ed. George Walter and R. K. R. Thornton (Ashington and Manchester, 1995); 80 Poems or So, ed. George Walter and R. K. R. Thornton (Ashington and Manchester, 1997); and Rewards of Wonder, ed. George Walter (Ashington and Manchester, 2000). There are also several selected editions.

12 'The Stokes Gunners’ is G.21A.78 in Gurney’s papers.

13 'La Rime' is G.21A.73 in Gurney’s papers, where it appears as 'Le Rime'. The error is most likely the result of a typist's mistranscription of Gurney's lost handwritten manuscript. Although tempted to keep the title unchanged for the remote possibility that it is not French at all but Italian plural, I have been swayed by the experiences of Michael Hurd, who reports that 'Gurney, in so far as his calligraphy permits accurate reading, seems to have been uncertain about the gender of "la guerre"' (The Ordeal of Ivor Gurney, p. 222). It seems sensible to give the benefit of the doubt to Gurney’s French over his 'calligraphy'. If a biographer struggles to decipher the difference between 'Le' and 'La', a typist working from handwritten manuscript copy will have been similarly challenged.

${ }^{14}$ This is Kavanagh’s original headnote in the 1982 Collected Poems, p. 261. In the revised edition, the headnote has become an endnote, which now reads: 'In this long autobiographical poem, one of many, Gurney describes his front-line experiences - even the shooting at people - in comic terms. This is typical of a certain vein in Gurney - perhaps typical of certain aspects of war' (p. 390).

${ }^{15}$ Siegfried Sassoon, The War Poems (1983), p. 66. 
16 'Joyeuse et Durandal' is G.21A.77 in Gurney’s papers. 